\title{
Heat waves in Poland in the period 1951-2015: trends, patterns and driving factors
}

\author{
Joanna Wibig \\ University of Lodz, Department of Meteorology and Climatology, Narutowicza 88, 90-139 Eódź, Poland, \\ e-mail: zameteo@uni.lodz.pl
}

\begin{abstract}
Heat waves were analysed on the basis of maximum daily temperature from 24 meteorological stations in Poland. Heat waves are defined as the longest continuous period during which Tmax (daily maximum air temperature) is equal to or higher than $30^{\circ} \mathrm{C}$ in at least three days, the mean $\operatorname{Tmax}$ during the whole heat wave is equal or higher than $30^{\circ} \mathrm{C}$ and $\operatorname{Tmax}$ does not drop below $25^{\circ} \mathrm{C}$ during the whole period of heat wave duration. Heat waves occur in Poland from April to September with their maximums in July and August. Four-day-long heat waves are most frequent but the longest one lasted 31 days. The most persistent heat waves were in 1994 and 2015. An increasing trend in heat wave frequency and intensity is observed in Poland, however the increase is statistically significant at only about $60 \%$ of analysed stations. Four synoptic patterns favouring heat waves have been distinguished. A strong high over the Azores accompanies all of them, as well as slightly higher than normal pressure over Central Europe this causes calm and sunny weather over Poland. Strong blocking appears over the North Atlantic during heat wave events, proofing that the development of strong heat waves in Poland is related to large scale circulation and that they are not of local origin. The analysis of the impact of soil moisture in months leading up to the development of heat waves should be the next step in analysis.
\end{abstract}

Keywords: heat wave, Poland, trend, intensity, blocking index, circulation pattern, $k$-mean clustering

Submitted 24 February 2017, revised 4 June 2017, accepted 9 October 2017

\section{Introduction}

In developed countries heat waves are regarded as a major cause of weather-related fatalities (Changnon et al. 1996; Karl, Knight 1997; De Bono et al. 2004; Vandentorren et al. 2004). According to the last IPCC report (IPCC 2013) »it is very likely that the number of cold days and nights has decreased and the number of warm days and nights has increased on the global scale«; also, »it is likely that the frequency of heat waves has increased in large parts of Europe, Asia and Australia«. Since the beginning of the twentieth century the temperature has been increasing and for regions such as Europe, for which there are historical temperature reconstructions going back several hundreds of years, the indications are that some areas have experienced a disproportionate number of extreme heat waves in recent decades (Hartmann et al. 2013).

In Poland and Czech Republic the heat wave which occurred in 1994 was very intensive and widespread (Kysely 2002; Wibig et al. 2009; Kysely 2010). A lot of attention has been devoted to the 2003 heat wave over Central-European countries (Beniston 2004; Black et al. 2004; Zaitchik et al. 2006), followed by another exceptional heat wave in July of 2006 in Central Europe (Kysely 2010), the heat wave in July 2010 in Eastern
Europe (Barriopedro et al. 2011) and the heat wave in Central Europe in August 2015 (Dong et al. 2016; Duchez et al. 2016). Due to global warming, it is very likely that the frequency and intensity of such events will increase in the future (Meehl, Tebaldi 2004; Schär et al. 2004).

So the question arises: has the frequency and intensity of heat waves increased? To answer this question it is necessary to formulate definitions of "heat wave" and their intensity, because a variety of measures that relate meteorological conditions to the human sensation of heat can be found in the literature (Driscoll 1985; Kalkstein, Valimont 1986; Hoppe 1999; Robinson 2001). A wide review of heat waves was made by Perkins and Aleksander (2013). Reviews of heat wave definitions used in Polish literature were made by Kuchcik (2006), Kossowska-Cezak (2010) and Krzyżewska (2014).

A definition of heat wave often includes a combination of weather elements related to human sensation of heat, with a duration and appropriate thresholds for daytime and nightime periods. Robinson (2001) suggested that for long-term countrywide analysis of heat wave variations, an index that relies on routine observations is desirable. There are two facets to the establishment of a threshold for heat waves. The first relies on a fixed value, the second uses percentiles. The criterion of duration is also important as there is evidence that the persistence of adverse condi- 
tions fosters an increase in mortality (Kalkstein, Smoyer 1993; Vandentorren et al. 2004; Hutter et al. 2007).

Heat waves in Poland have been analysed by several authors. Wibig et al. (2009) have shown that the frequencies of very warm and hot days increased in the period 1951-2006, especially in the second part of this period (1979-2006). The analysis was performed using records from six stations in Poland. The frequency of hot days increased at all analysed stations, but this increase was only significant at four of them. Heatwaves were also analysed at selected sites in the Wyżyna Kielecka (Jarzyna 2012) and in Warsaw (Kossowska-Cezak, Skrzypczuk 2011). Twardosz and Kossowska-Cezak (2013) analysed thermal extremes in Central Europe on the basis of data from 54 stations. They distinguished extremely hot summers, i.e., summers having an average temperature equal to or greater than the long-term average plus two standard deviations and analysed the frequencies of days with $t_{\max }$ exceeding selected thresholds. Krzyżewska and Wereski (2011) analysed waves of both heat and cold in bioclimatic regions over the short period of 2000-2010. Tomczyk and Bednorz (2016) have shown that the occurrence of heat waves was mainly connected with positive anomalies in sea level pressure and the $500 \mathrm{hPa}$ level geopotential height indicating the presence of high-pressure systems. They have also shown that heat waves in Central Europe were usually accompanied by positive T850 and precipitable water anomalies. Similar results were obtained by Porębska and Zdunek (2013), who showed that prolonged high pressure blocking events in summer accompany the occurrence of positive thermal anomalies. Duchez et al. (2016) for the specific case of 2015, showed that an ocean anomaly can cause the Jet Stream to have a stationary position, thus favouring the development of high surface temperatures over Central Europe during a heat wave.

This paper has two main aims: 1) to investigate the variability and long-term changes of frequencies and intensities of heat waves and 2) to investigate the relationship between heat wave occurrence and atmospheric circulation. Section 2 presents the data and discusses the methods used in the study. Section 3 presents the variability and longterm changes of frequencies and intensities of heat waves. Section 4 shows how the heat waves are conditioned by the atmospheric circulation. A discussion of the results, followed by conclusions, is presented in Section 5 .

\section{Data and methods}

\subsection{Heat wave definition}

In the paper the definition of heat wave used by Huth et al. (2000) is used. It defines a heat wave as the longest continuous period during which Tmax (daily maximum air temperature) is equal to or higher than $30^{\circ} \mathrm{C}$ in at least three days, the mean Tmax during the whole heat wave is equal to or higher than $30^{\circ} \mathrm{C}$, and $\operatorname{Tmax}$ does not drop below $25^{\circ} \mathrm{C}$ during the whole period.

\subsection{Data}

Heat waves are described using maximum daily temperature records from 24 meteorological stations in Poland covering the period 1951-2015. The locations of these stations are presented in Fig. 1. Data were provided by the Institute of Meteorology and Water Management (IMGW-PIB) in Poland.

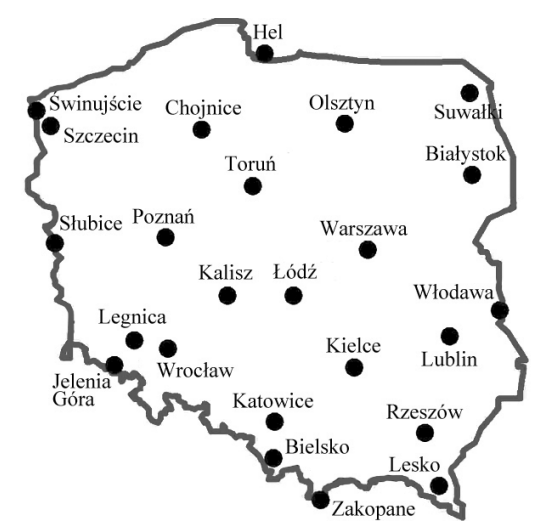

Fig. 1. Location of meteorological stations

To describe the atmospheric circulation, the daily sea level pressure values from NCEP/NCAR reanalysis from the period 1951-2015 were used (Kalnay et al. 1996). Data from the area $60^{\circ} \mathrm{W}$ to $60^{\circ} \mathrm{E}$ and $30^{\circ}-70^{\circ} \mathrm{N}$ were extracted for this paper.

To calculate the blocking index $(B I)$ daily $500 \mathrm{hPa}$ geopotential height from the same reanalysis were used. Data for two latitudes $40^{\circ}$ and $60^{\circ} \mathrm{N}$ were used from the hemisphere spreading from $90^{\circ} \mathrm{W}$ to $90^{\circ} \mathrm{E}$.

\subsection{Measures of heatwave frequency, severity and long-term variability}

To present the statistics of heat waves in Poland, the monthly frequencies and relative frequencies of heat waves were calculated together with monthly frequencies and relative frequencies of the amount of days in heat waves. Heat wave severity $(H W S)$ was defined as the sum of temperature surplus over $30^{\circ} \mathrm{C}$ for all days in a heat wave:

$$
H W S=\sum_{i=1}^{n}\left(\operatorname{tmax}_{i}-30\right)
$$

where $\operatorname{tmax}_{i}$ denotes the maximum air temperature on day $i$ and $n$ denotes the number of days in a heat wave. 
The long-term variability of frequencies, number of days in heatwaves and $H W S$ were analysed. As not all variables are normally distributed, the nonparametric Mann-Kendall was used to detect trends (Mann 1945; Hamed 2008). This test is based on a rank correlation of the observed values and their order in time. The MannKendall test statistic $\mathrm{S}$ is defined as:

$$
S=\sum_{k=1}^{n=1} \sum_{j=k+1}^{n} \operatorname{sgn}\left(x_{j}-x_{k}\right)
$$

where:

$$
\operatorname{sgn}\left(x_{j}-x_{k}\right)=\left\{\begin{array}{lll}
+1 & \text { if } & \left(x_{j}-x_{k}\right)>0 \\
0 & \text { if } & \left(x_{j}-x_{k}\right)=0 \\
-1 & \text { if } & \left(x_{j}-x_{k}\right)<0
\end{array}\right.
$$

and $n$ is the length of the series. The statistics $S$ approximates a normal distribution with mean $E(S)=0$ and a variance $\operatorname{var}(S)$ defined as:

$$
\operatorname{var}(S)=\frac{1}{18} \cdot\left(n(n-1)(2 n+5)-\sum_{i=1}^{p}\left(t_{i}\left(t_{i}-1\right)\left(2 t_{i}+5\right)\right)\right.
$$

where $p$ is the number of ties (values that have duplicates in the series) and $t_{i}$ is the number of duplicates for tie $i$.

\subsection{Blocking index and clustering of weather types}

Blocking is a synoptic situation when a basic westerly current is splitted into two branches, each of them transporting an appreciable air mass (Lejenäs, Øakland 1983). During such a situation there is an abrupt transition from zonal to meridional flow and this situation persists for a few days at least. Lejenäs and Øakland (1983) proposed a measure of the blocking as the difference between values of geopotential height at $500 \mathrm{hPa}$ level on two latitudes $40^{\circ} \mathrm{N}$ and $60^{\circ} \mathrm{N}$ :

$$
B I(\lambda)=Z_{40 \circ \mathrm{N}}(\lambda)-Z_{60} \mathrm{~N}(\lambda)
$$

where $\lambda$ is a longitude and $Z_{40^{\circ} \mathrm{N}}$ and $Z_{60^{\circ} \mathrm{N}}$ are geopotential heights at $500 \mathrm{hPa}$ level at gridpoints with latitude $40^{\circ} \mathrm{N}$ and $60^{\circ} \mathrm{N}$ respectively and longitude $\lambda$. To check the relation of blocking with the occurrence heat waves, the difference between an average blocking index on heatwave days with an average blocking index on all summer days was analysed (summer lasts from $1^{\text {st }}$ June to $31^{\text {st }}$ August).

Many papers have suggested that atmospheric circulation is one of the most important reasons for heat waves. To find weather types favouring heat wave occurrence all days with heat waves were divided into a few clusters characterising similar synoptic situations. The $k$-means cluster- ing was used to distinguish weather types favouring the occurrence of heat. The synoptic situations were described by daily sea level pressure (SLP) fields on the area from $60^{\circ} \mathrm{W}$ to $60^{\circ} \mathrm{E}$ and from $30^{\circ}$ to $70^{\circ} \mathrm{N}$. Gridded data with a resolution of 2,5 degrees were used. Daily fields from 795 days were extracted from NCEP/NCAR reanalysis (Kalnay et al. 1996). The $k$-means algorithm was used to find the optimum division of all days into 4 clusters, as this number was suggested by principal component analysis. Initial cluster centres were chosen to maximize initial between cluster distances, then the average SLP fields within each cluster were calculated and compared.

\section{Frequencies and intensities of heat waves}

In the analysed 65 year period heat waves were observed at each station on average once per two years. They appeared most often in Słubice (56 waves over 65 years), Poznań (54 waves), Kalisz (53 waves) and Legnica (52 waves). All these stations are located in the central part of western Poland. Heat waves were observed least frequently in Hel (only 2 waves over 65 years), Zakopane (3 waves) and Świnoujście (4 waves). These stations are located at the coast or in the mountains. Heat waves can appear in Poland from April to September (Fig. 2). $49,13 \%$ of all heat wave days happened in July, 38,63\% in August and 9,88\% in June. Only 2,76\% of days in heat waves occurred in April (5 station-days); in May there were 29 such days and in September there were 80.

When the length of heat waves was analysed, the frequencies of heat waves were assessed in the function of their length (Fig. 3). The most common were heat waves lasted four days. These appeared in more than $28 \%$ of all cases. Heat waves lasting 3 and 5 days appear slightly less often (18 and 16\% respectively). Heat waves of a length of 6-9 days were observed in more than $5 \%$ of cases each. 10-16-day-long waves made up a little more than $1 \%$ of heatwaves. The longest wave lasted 31 days (Słubice, from $2^{\text {nd }}$ August to $1^{\text {st }}$ September 2015), and the next one lasted only 22 days (Szczecin, $21^{\text {st }}$ July $-11^{\text {th }}$ August 1994).

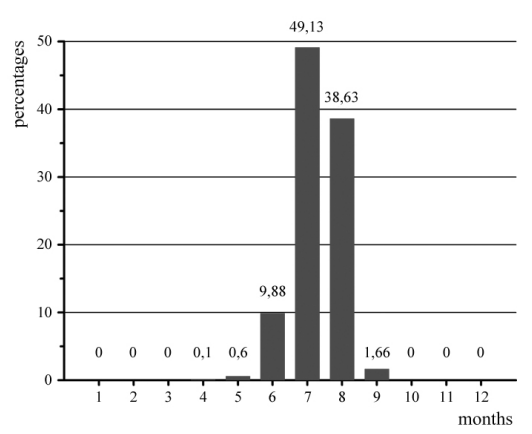

Fig. 2. Annual course of heat wave occurrence in Poland during the period 1951-2015 


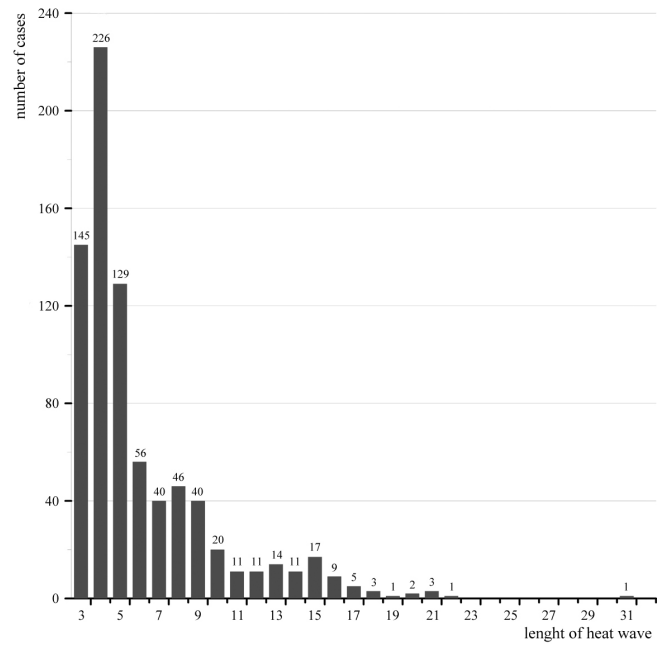

Fig. 3. Frequencies of heat waves in function of their length in the Poland during the period 1951-2015

Sixteen of the longest waves are collected in Table 1 . As can be seen from this table they all happened during two periods. The first occurred in 1994, and long heat waves lasting ceaselessly for at least 17 days were observed at 12 from all the 24 stations analysed in this paper. The second occurred in August 2015 and at 4 stations lasted ceaselessly for at least 17 days. The heat wave in July/August 1994 was also the longest single heat wave (before 2009) at a majority of sites in Czech Republic (Kysely 2010).

The severity of heat waves was measured using the $H W S$ index which describe the severity as a cumulative surplus of temperature above $30^{\circ} \mathrm{C}$ at single stations. The most frequent are waves with an $H W S$ from the interval $\left(0^{\circ} \mathrm{C}, 5^{\circ} \mathrm{C}>\right.$. This is $58 \%$ of all heatwaves (Fig. 4).

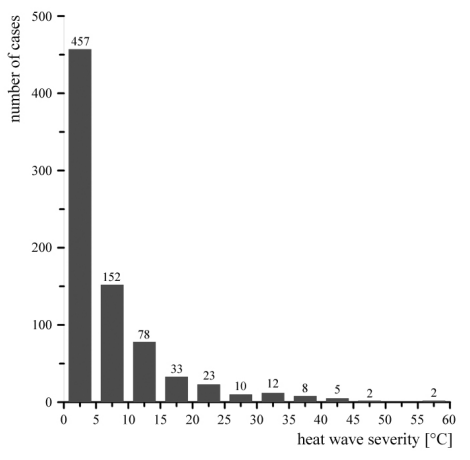

Fig. 4. Frequencies of heat waves in function of their severity in Poland during the period 1951-2015

The most severe heat waves have $H W S$ above $55^{\circ} \mathrm{C}$. The other attribute of heat waves describe their spatial coverage. This was measured by the number of stations with a heat wave on particular day (Fig. 5). On $28 \%$ of all heat wave days the heat wave was observed only at one station. The most widespread waves encompass 22 of 24 stations on 4 days, 21 stations on 13 days and 20 stations on 9 days. The heat waves spreaded over more than two thirds of stations are collected in Table 2. The majority of them happened in the $21^{\text {st }}$ century, with three in the extremely warm year of 2015. The simultaneously most prolonged and widespread were two heat waves, which occurred at the turn of July and August 1994 and in August 2015.

The existence of a long term positive trend in the number of days with heat waves and HWS index were tested using the Mann-Kendall test (Table 3). A statistically significant $95 \%$ level increasing tendency was shown for 15 of 24 stations in the number of days with heat waves

Table 1. Sixteen of the longest heat waves in Poland during the period 1951-2015

\begin{tabular}{|l|c|c|l|c|c|}
\hline $\begin{array}{l}\text { Meteorological } \\
\text { station }\end{array}$ & Length & \multicolumn{1}{|c|}{ Period } & $\begin{array}{l}\text { Meteorological } \\
\text { station }\end{array}$ & Lenght & Period \\
\hline Słubice & 31 & $02.08 .-01.09 .2015$ & Poznań & 18 & $02.08 .-19.08 .2015$ \\
\hline Szczecin & 22 & $21.07 .-11.08 .1994$ & Rzeszów & 18 & $24.07 .-10.08 .1994$ \\
\hline Słubice & 21 & $22.07 .-10.08 .1994$ & Włodawa & 18 & $24.07 .-10.08 .1994$ \\
\hline Legnica & 21 & $22.07 .-10.08 .1994$ & Kalisz & 17 & $23.07 .-08.08 .1994$ \\
\hline Wrocław & 21 & $22.07 .-10.08 .1994$ & Legnica & 17 & $03.08 .-19.08 .2015$ \\
\hline Chojnice & 20 & $24.07 .-12.08 .1994$ & Lódź & 17 & $23.07 .-08.08 .1994$ \\
\hline Toruń & 20 & $24.07 .-12.08 .1994$ & Lublin & 17 & $23.07 .-08.08 .1994$ \\
\hline Poznań & 19 & $24.07 .-11.08 .1994$ & Toruń & 17 & $03.08 .-19.08 .2015$ \\
\hline
\end{tabular}

Table 2. The periods with the most widespread heat waves in Poland during the period 1951-2015

\begin{tabular}{|c|c|c|c|c|c|c|c|}
\hline No. & Onset & End & Length & No. & Onset & End & Length \\
\hline 1 & 10.07 .1959 & 13.07 .1959 & 4 & 6 & 11.07 .2010 & 15.07 .2010 & 5 \\
\hline 2 & 24.07 .1963 & 01.08 .1963 & 9 & 7 & 04.07 .2015 & 07.07 .2015 & 4 \\
\hline 3 & 17.06 .1968 & 19.06 .1968 & 3 & 8 & 03.08 .2015 & 16.08 .2015 & 14 \\
\hline 4 & 26.07 .1994 & 08.08 .1994 & 14 & 9 & 30.08 .2015 & 02.09 .2015 & 4 \\
\hline 5 & 16.07 .2007 & 18.07 .2007 & 3 & & & & \\
\hline
\end{tabular}


Table 3. The presence of statistically significant trend in the number of days in heat waves (days) and the HWS index (severity) during the period 1951-2015 according to the MannKendall test

\begin{tabular}{|l|c|c|l|c|c|}
\hline $\begin{array}{l}\text { Meteorological } \\
\text { station }\end{array}$ & Days & Severity & $\begin{array}{l}\text { Meteorological } \\
\text { station }\end{array}$ & Days & Severity \\
\hline Białystok & - & - & Olsztyn & + & - \\
\hline Bielsko-Biała & + & + & Poznań & + & + \\
\hline Chojnice & - & - & Rzeszów & + & + \\
\hline Hel & - & - & Słubice & + & + \\
\hline Jelenia Góra & - & - & Suwałki & + & + \\
\hline Kalisz & + & + & Świnoujście & - & - \\
\hline Katowice & + & + & Szczecin & - & - \\
\hline Kielce & - & - & Toruń & + & + \\
\hline Legnica & + & + & Warszawa & + & + \\
\hline Lesko & - & - & Włodawa & + & + \\
\hline Lódź & + & + & Wrocław & + & + \\
\hline Lublin & - & - & Zakopane & + & + \\
\hline
\end{tabular}

and for 14 of 24 stations where the severity index was analysed. These positive trends have also been shown by other authors (Wibig et al. 2009; Tomczyk, Bednorz 2016). The lack of statistical significance of trends at some places is related to the rare occurrence of heat waves in the case of coastal and mountainous stations and very high year-toyear variability in the case of all stations.

However, there is a strong relationship between the anomaly of average July-August maximum temperature and the HWS index (Kysely 2002). High positive anomalies occur in years with a high cumulated HWS index (sum of all $H W S$ values during the year). At the majority of stations, the heat waves in years 1959, 1963, 1968, 1992, 1994, 2006, 2010 and 2015 are the most evident.

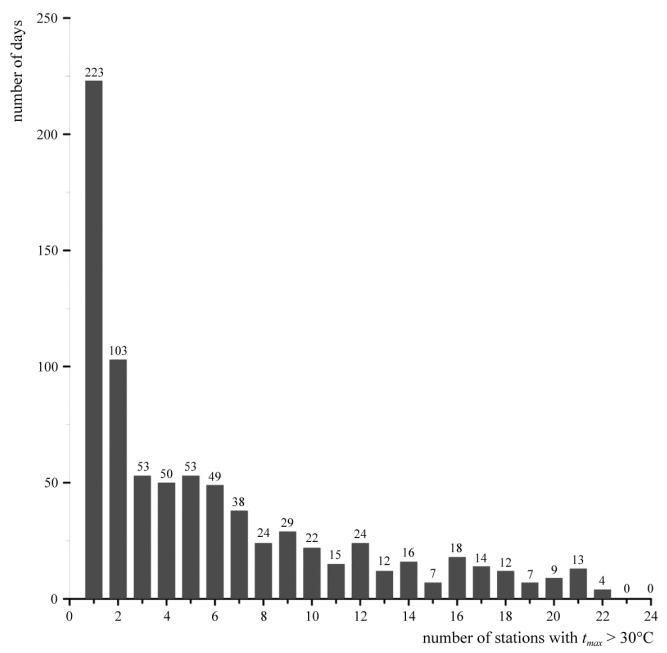

Fig. 5. Frequencies of heat waves in function of their spatial range in Poland during the period 1951-2015

The example of Torun is shown in Fig. 6. The increase in summer maximum temperature which is reported by many authors (Twardosz, Kossowska-Cezak 2013; Hartman et. al. 2013; Rutgersson et al. 2015), means that the probability of long and widespread heat wave occurrence is also increasing.

\section{Atmospheric circulation favouring heat wave occurrence}

The $k$-mean clustering method was used to distinguish four typical situations favouring the development of heat waves. The mean SLP fields for these clusters are presented in Fig. 7. On all four maps the strong high-pressure system over the Atlantic Ocean in the latitudes $30-40^{\circ} \mathrm{N}$ and low pressure system over the Asia Minor region can be seen. Higher than usual pressure also exists over Cen-

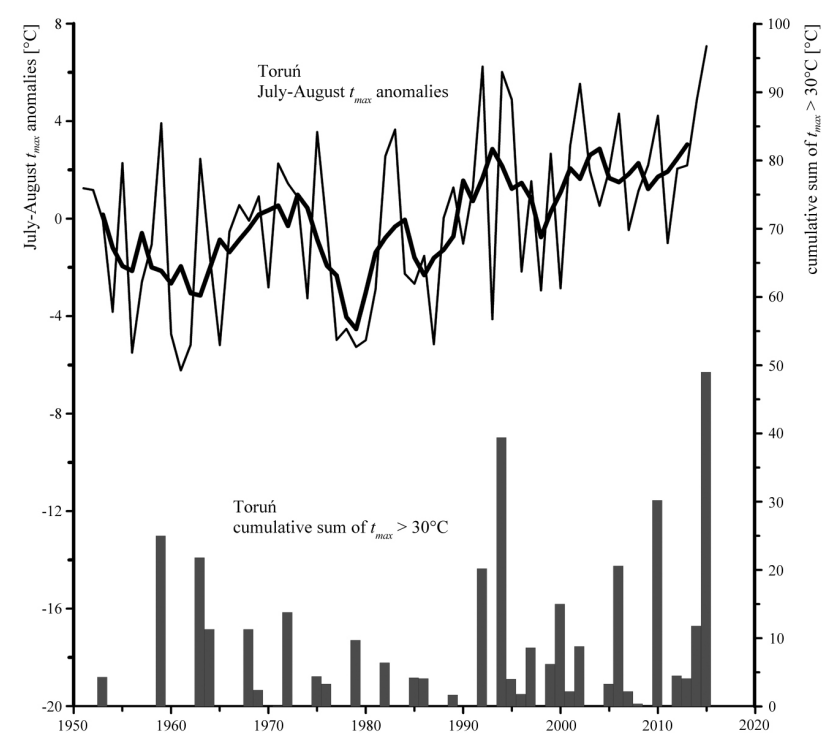

Fig. 6. The upper graph and left scale presents the mean July-August maximum temperature anomalies (thin line - annual values, thick line - seven year running averages); bars on the lower graph and right scale show the cumulative sum of $\operatorname{tmax}>30^{\circ} \mathrm{C}$ during heat wave days, i.e., cumulative HWS index; they are both for Torun and for the period 1951-2015 

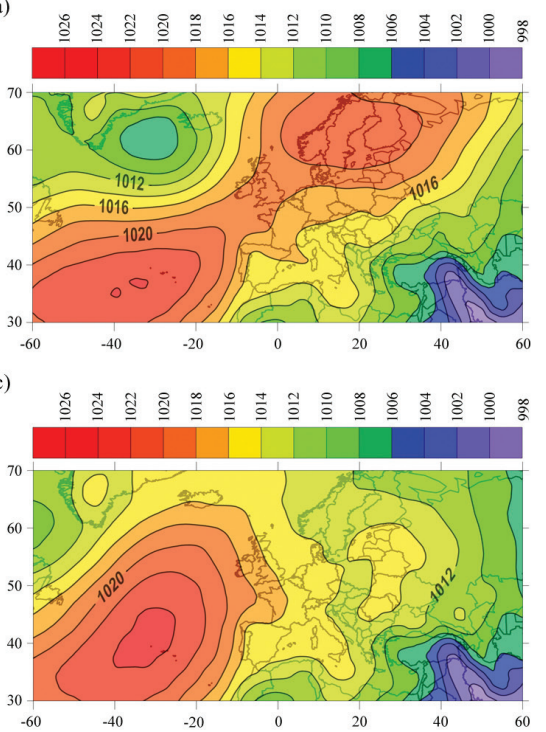

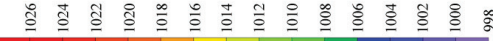

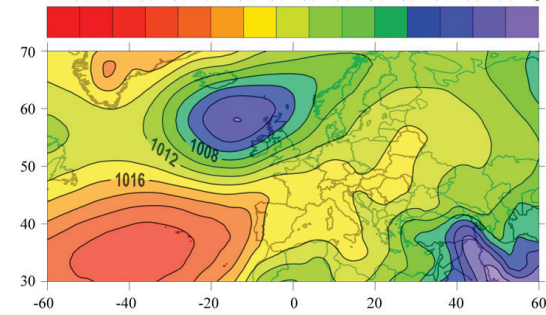

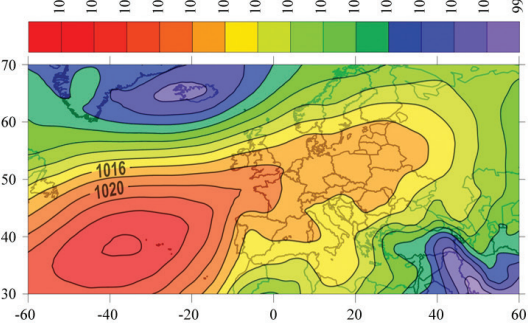

Fig. 7. The mean SLP for heat wave days belonging to four types distinguished by the $k$-mean method during the period 1951-2015; a - type 1, 180 days; $\mathrm{b}$ - type 2, 162 days; $\mathrm{c}$ - type 3, 243 days; $\mathrm{d}$ - type 4, 210 days

tral Europe and Poland. The maps differ in the location and intensity of the low over the Northern Atlantic and the intensity of the high-pressure system over Poland. The most frequent (243 days) is the pattern with a highpressure system spreading far north over the Northern Atlantic with absence of low-pressure system between Greenland and Europe and a weak high-pressure wedge spreading over Europe (Fig. 7c). In Poland this is connected with sunny and calm weather. Slightly less frequent (210 days) is the pattern with a well-developed Azorian High with a wedge spreading far to the north-east up to Russia (Fig. 7d). The Icelandic Low is also well developed, but moved to the north. The strong SLP gradient is present in the northern part of Europe, but over the central part of the continent - including Poland, high pressure dominates - this is associated with calm and sunny weather. The next pattern, which occurred over 180 days (Fig. 7a), is characterised by the presence of two highs, one centred over the Azores and the second centred over the Scandinavian peninsula, linked by high-pressure ridge. Two lowpressure systems are also present, a stronger one over Asia Minor and a weaker one between Greenland and Iceland.

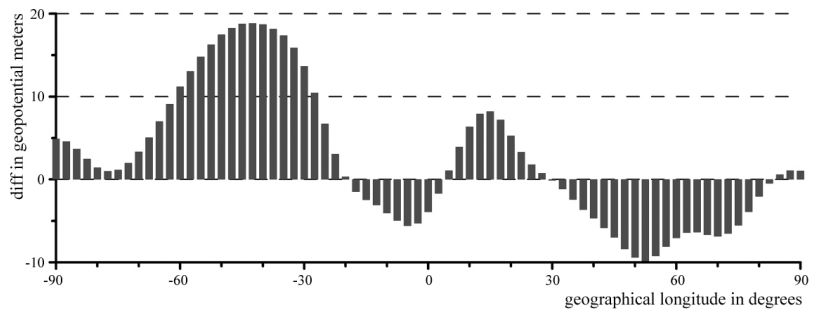

Fig. 8. The difference between an average blocking index ( $B I)$ during days with heat waves and an average $B I$ on all summer days in the function of longitude from $90^{\circ} \mathrm{W}$ to $90^{\circ} \mathrm{E}$, for the period 1951-2015
Poland is located at the southern part of the Scandinavian High. The pressure gradient over Poland is very low, so the weather is calm and sunny. The least frequent (162 days) is the pattern with a strong high centered over the Azores with a wedge spreading to the north-east (Fig. 7b). The Icelandic Low is at its climatological position and is relatively strong, but the main stream of air mass advection occurs over Scandinavia. Over the area of Poland the pressure gradient is also very low and it contributes to sunny and calm weather in Poland and surrounding countries. All these patterns are characterised by strong blocking determined by a persistent and widespread high pressure system over the Northern Atlantic close to the Azores. The existence of high pressure over the Azores is very important, much more than the existence of strong high pressure over Poland. This is also indicated by the anomalies of the blocking index calculated for latitudes $40-60^{\circ} \mathrm{N}$. As is shown in Fig. 8, the positive blocking anomalies during heat wave days are the strongest for longitudes $70-20^{\circ} \mathrm{W}$ (i.e., over the Atlantic Ocean) and weaker for longitudes $5-30^{\circ} \mathrm{E}$ (i.e., over Central Europe and Poland).

\section{Discussion and conclusions}

Heat waves can happen in Poland from April to September, but they are most common in July and August, when almost $90 \%$ of all heat wave days occurred in the period 1951-2015. On average, they were observed at each station once per two years, most frequently in the central part of western Poland (almost one per year), least frequently at the coast and in the mountains (one per 20-30 years). There were a few years with intense heat waves: 1959, 1963, 1968, 1992, 1994, 2006, 2010 and 2015. However, 
their intensity is strongly relate to the chosen definition and measure. The number of heat waves is very sensitive to average maximum temperature and sometimes a small increase in temperature can cause two short heat waves to merge into a longer one, so the weather conditions are more extreme in spite of a lower number of heat waves. The other measure used in this paper is the total number of days in heat waves. This expresses the persistence of hot conditions, but a few short waves with a temperature only slightly exceeding $30^{\circ} \mathrm{C}$ are less persistent than one long heat wave with a really high temperature, even if the total number of days is lower. So some measures of heat wave intensity were used as a cumulative sum of temperature surplus over $30^{\circ} \mathrm{C}$. The other extremity indices considering both the intensity of a heat wave at particular place and the spread of high temperatures were not analysed in this paper, because the number of stations and the distances between them were not sufficient for robust analysis. The heat wave spread was measured by a number of stations, at which a heat wave was simultaneously observed. Only nine heat waves in the analysed 65-year period were spread over more than two-thirds of the stations at the same time. Three of them happened at the beginning of the analysed period, in the years 1959, 1963 and 1968. Five happened in the $21^{\text {st }}$ century and three of them in the extremely hot year of 2015 .

The long term trend of heat waves was analysed applying the nonparametric Mann-Kendall test to series of the annual number of days with heat waves and annual heat wave intensities. The increase was observed at 23 of 24 stations and at 15 the increase was statistically significant (at 14 in the case of intensity). They were not significant at coastal and mountainous stations because of their great rarity. The other reason for a lack of significance is the very high year-to-year variability of both measures. It is worth noting that the increase in heat wave intensity was not steady. Heat waves were relatively frequent in the $1950 \mathrm{~s}$ and $60 \mathrm{~s}$, rare in the $70 \mathrm{~s}$ and $80 \mathrm{~s}$, and their intensity has evidently been increasing since the beginning of the 90s. This follows changes in the average daily maximum temperature in summer. It is the main reason why we suspect that the frequency and intensity of heat waves will continuously increase in the future (Hartmann et al. 2013). Similar results were obtained by Tomczyk and Bednorz (2016). They looked for heat waves in the period 19712010 and found them to be slightly more frequent than in this paper. Their mean annual number varied from 0,25 at the coast to almost 1 in the south-western part of Poland. They defined a heat wave as a period lasting at least 5 days with maximum air temperature exceeding the $95^{\text {th }}$ percentile, so the threshold value varied from less than $24^{\circ} \mathrm{C}$ at the coast to about $28^{\circ} \mathrm{C}$ in the south of Poland. Lower threshold with a longer duration caused the frequency of heat waves to be slightly higher. In spite of some differences in frequency the period of possible occurrence (from April to September) is exactly the same. Long-term trends in both papers are also similar.

The occurrence of heat waves in Poland is determined by the presence of a deep high over middle latitudes of the North Atlantic, with a ridge of high pressure spreading into the north-east. It is always associated with higher than usual pressure over Poland and a weak pressure gradient in this area. Such patterns result in calm and sunny weather. Patterns very similar to those shown in Fig. 7 have also been distinguished by Tomczyk and Bednorz (2016) using a different classification method, thus reaffirming the correctness of the conclusions. Types 1, 2 and 3 from their paper (Figs. 7a, 8a and 9a) correspond with types 1, 2 and 4 (Figs. 7a-b and d) of this one. Anticyclones have also been indicated as a main reason for the development of heat waves by Wibig et al. (2009) and Porębska and Zdunek (2013). However, on all these maps the deep highpressure system is located close to the Azores. Analysis of the blocking index defined by Lejenäs and Øakland (1983) as the difference between values of geopotential height at $500 \mathrm{hPa}$ level at two latitudes, $40^{\circ} \mathrm{N}$ and $60^{\circ} \mathrm{N}$, shows that heat waves in Poland occur when strong blocking over the Atlantic Ocean is observed. A positive blocking anomaly over Central Europe is also present, but is much weaker. This means that when analysing the circulation patterns accompanying heat waves it is better to also include the SLP over the Northern Atlantic, because the presence of well-developed Azorian High is a key factor for their occurrence.

There are some suggestions that soil moisture in spring and early summer is a factor that affects the development of heat waves in summer (Seneviratne et al. 2010; Keggenhoff et al. 2015). In the next step of research on heat wave development in Poland, the impact of soil moisture should be considered.

\section{Bibliography}

Barriopedro D., Fischer E.M., Luterbacher J., Trigo R.M., García-Herrera R., 2011, The hot summer of 2010: redrawing the temperature record map of Europe, Science, 332 (6026), 220-224, DOI: $10.1126 /$ science. 1201224

Beniston M., 2004, The 2003 heat wave in Europe: a shape of things to come? An analysis based on Swiss climatological data and model simulations, Geophysical Research Letters, 31 (2), L02202, DOI: 10.1029/2003GL018857 
Black E., Blackburn M., Harrison G., Hoskins B., Methven J., 2004, Factors contributing to the summer 2003 European heatwave, Weather, 59 (8), 217-223, DOI: 10.1256/wea.74.04

Changnon S.A., Kunkel K.E., Reinke B.C., 1996, Impacts and responses to the 1995 heat wave: a call to action, Bulletin of the American Meteorological Society, 77, 1497-1506, DOI: 10.1175/1520-0477(1996)077<1497:IARTTH>2.0.CO;2

De Bono A., Giuliani G., Kluser S., Peduzzi P., 2004, Impacts of summer 2003 heat wave in Europe, Europe Environment Alert Bulletin, 2, 1-4

Dong B., Sutton R., Shaffrey L., Wilcox L., 2016, The 2015 European heat wave, special supplement to the Bulletin of the American Meteorological Society, 97 (12), S14-S18, DOI: 10.1175/BAMS-D-16-0149

Driscoll D.M., 1985, Human health, [in:] Handbook of applied meteorology, D.D. Houghton (ed.), John Wiley and Sons, 778-814

Duchez A., Frajka-Williams E., Josey S.A., Evans D.G., Grist J.P., Marsh R., McCarthy G.D., Sinha B., Berry D.I., Hirschi J.J.-M., 2016, Drivers of exceptionally cold North Atlantic Ocean temperatures and their link to the 2015 European heat wave, Environmental Research Letters, 11 (7), 9 pp., DOI: 10.1088/1748-9326/11/7/074004

Hamed K.H., 2008, Trend detection in hydrologic data: the Mann-Kendall trend test under the scaling hypothesis, Journal of Hydrology, 349 (3-4), 350-363, DOI: 10.1016/j. jhydrol.2007.11.009

Hartmann D.L., Klein Tank A.M.G., Rusticucci M., Alexander L.V., Dronnimann S., Charabi Y., Dentener F.J., Dlugokencky E.J., Easterling D.R., Kaplan A., Soden B.J., Thorne P.W., Wild M., Zhai P.M., 2013, Observations: atmosphere and surface, [in:] Climate change 2013: the physical science basis. Contribution of Working Group I to the Fifth Assessment Report of the Intergovernmental Panel on Climate Change, T.F. Stocker, D. Qin, G.-K. Plattner, M. Tignor, S.K. Allen, J. Boschung, A. Nauels, Y. Xia, V. Bex, P.M. Midgley (eds.), Cambridge University Press, Cambridge, United Kingdom and New York, NY, USA, 159-254

Hoppe P., 1999, The physiological equivalent temperature a universal index for the biometeorological assessment of the thermal environment, International Journal of Biometeorology, 43 (2), 71-75, DOI: 10.1007/s004840050118

Huth R., Kysely J., Pokorná L., 2000, A GCM simulation of heat waves, dry spells, and their relationship to circulation, Climatic Change, 46 (1-2), 29-60, DOI: 10.1023/A:1005633925903

Hutter H.P., Moshammer H., Wallner P., Leitner B., Kundi M., 2007, Heatwaves in Vienna: effects on mortality, Wiener Klinische Wochenschriften, 119 (7-8), 223-227, DOI: 10.1007/s00508-006-0742-7

IPCC, 2013, Summary for Policymakers, [in:] Climate change 2013: the physical science basis. Contribution of Working
Group I to the Fifth Assessment Report of the Intergovernmental Panel on Climate Change, T.F. Stocker, D. Qin, G.-K. Plattner, M. Tignor, S.K. Allen, J. Boschung, A. Nauels, Y. Xia, V. Bex, P.M. Midgley (eds.), Cambridge University Press, Cambridge, United Kingdom and New York, NY, USA, 3-29

Jarzyna K., 2012, Thermal stress diversity during heat waves in the Kielecka Upland in the beginning of XXI century, (in Polish), Monitoring Środowiska Przyrodniczego, 13, 41-50

Kalkstein L.S., Smoyer K.E., 1993, The impact of climate change on human health: some international implications, Experientia, 49 (11), 969-979

Kalkstein L.S., Valimont K.M., 1986, An evaluation of summer discomfort in the United States using a relative climatological index, Bulletin of the American Meteorological Society, 67 (7), 842-848, DOI: 10.1175/1520-0477(1986)067<0842:AEOSD $\mathrm{I}>2.0 . \mathrm{CO} ; 2$

Kalnay E., Kanamitsu M., Kistler R., Collins W., Deaven D., Gandin L., Iredell M., Saha S., White G., Woollen J., Zhu Y., Leetmaa A., Reynolds R., 1996, The NCEP/NCAR 40-Year Reanalysis Project, Bulletin of the American Meteorological Society, 77 (3), 437-472, DOI: 10.1175/1520-0477(1996)077<0437:TNYRP > 2.0.CO;2

Karl T.R., Knight R.W., 1997, The 1995 Chicago heat wave: how likely is a recurrence?, Bulletin of the American Meteorological Society, 78 (6), 1107-1119, DOI: 10.1175/1520-0477(1997)078<1107:TCHWHL $>2.0$. CO;2

Keggenhoff I., Elizbarashvili M., King L., 2015, Severe summer heat wavesover Georgia: trends, patterns and driving forces, Earth System Dynamics Discussions, 6, 2273-2322, DOI: 10.5194/esdd-6-2273-2015

Kossowska-Cezak U., 2010, Heat waves and heat periods - distinguishing methods and results of application, (in Polish), Prace Geograficzne, 123, 143-149

Kossowska-Cezak U., Skrzypczuk J., 2011, Hot weather in Warsaw (1947-2010), (in Polish), Prace i Studia Geograficzne, $47,139-146$

Krzyżewska, A., 2014: The review of the methods defining heat waves and frost waves, (in Polish), Przegląd Geofizyczny, LIX (3-4), 157-173

Krzyżewska A., Wereski S., 2011, Heat wavesand frost waves in selected Polish stations against bioclimatic regionsbackground (200-2010), (in Polish), Przegląd Geofizyczny, LVI (1-2), 99-109

Kuchcik M., 2006, Defining heat wave - different approaches, Geographia Polonica, 79 (2), 47-63

Kysely J., 2002, Temporal fluctuations in heat waves at PragueKlementinum, the Czech Republic, from 1901-1997, and their relationships to atmospheric circulation, International Journal of Climatology, 22, 33-50, DOI: 10.1002/joc.720 
Kysely J., 2010, Recent severe heat waves in central Europe: how to view them in a long-term prospect?, International Journal of Climatology, 30 (1), 89-109, DOI: 10.1002/joc.1874

Lejenäs H., Øakland H., 1983, Characteristics of the northern hemisphere blocking as determined from a long time series of observational data, Tellus, 35A (5), 350-362, DOI: 10.1111/j.1600-0870.1983.tb00210.x

Mann H.B., 1945, Nonparametric tests against trend, Econometrica, 13 (3), 245-259, DOI: 10.2307/1907187

Meehl G.A., Tebaldi C., 2004, More intense, more frequent, and longer lasting heat waves in the $21^{\text {st }}$ century, Science, 305 (5686), 994-997, DOI: 10.1126/science.1098704

Perkins S.E., Alexander L.V., 2013, On the measurement of heat waves, Journal of Climate, 26, 4500-4517, DOI: 10.1175/ JCLI-D-12-00383.1

Porębska M., Zdunek M., 2013, Analysis of extreme temperature events in Central Europe related to high pressure blocking situations in 2001-2011, Meteorologische Zeitschrift, 22 (5), 533-540, DOI: 10.1127/0941-2948/2013/0455

Robinson P.J., 2001, On the definition of a heat wave, Journal of Applied Meteorology, 40, 762-775, DOI: 10.1175/1520-0450(2001)040<0762:OTDOAH >2.0.CO;2

Rutgersson A., Jaagus J., Schenk F., Stendel M., Bärring L., Briede A., Claremar B., Hanssen-Bauer I., Holopainen J., Moberg A., Nordli Ø., Rimkus E., Wibig J., 2015, Recent change - atmosphere, [in:] Second Assessment of Climate Change for the Baltic Sea Basin, The BACC II Author team, Springer, 69-97

Schär C., Vidale P.L., Lüthi D., Frei C., Häberli C., Liniger M., Appenzeller C., 2004, The role of increasing temperature variability in European summer heat waves, Nature, 427, 332-336, DOI: 10.1038/nature02300

Seneviratne S.I., Corti T., Davin E.L., Hirschi M., Jaeger E.B., Lehner I., Orlowsky B., Teuling A.J., 2010, Investigating soil moisture - climate interactions in a changing climate: a review, Earth-Science Reviews, 99 (3-4), 125-161, DOI: 10.1016/j.earscirev.2010.02.004

Tomczyk A.M., 2014, Circulation-related conditioning of the occurrence of heatwaves in Poznań, (in Polish), Przegląd Geograficzny, 86, 41-52

Tomczyk A.M., Bednorz E., 2016, Heat waves in Central Europe and their circulation conditions, International Journal of Climatology, 36 (2), 770-782, DOI: 10.1002/joc.4381

Twardosz R., Kossowska-Cezak U., 2013, Exceptionally hot summers in Central and Eastern Europe (1951-2010), Theoretical and Applied Climatology, 112 (3-4), 617-628, DOI: 10.1007/s00704-012-0757-0

Vandentorren S., Suzan F., Medina S., Pascal M., Maulpoix A., Cohen J.-C., Ledrans M., 2004, Mortality in 13 French cities during the August 2003 heat wave, American Journal of Public Health, 94 (9), 1518-1520

Wibig J., Podstawczyńska A., Rzepa M., Piotrowski P., 2009, Heatwaves in Poland - frequency, trends and relationships with atmospheric circulation, Geographia Polonica, 82 (1), 33-46

Zaitchik B.F., Macalady A.K., Bonneau L.R., Smith R.B., 2006, Europe's 2003 heat wave: a satellite view of impacts and land-atmosphere feedbacks, International Journal of Climatology, 26, 743-769, DOI: 10.1002/joc. 1280 
